\title{
Fitoremediasi Logam Timbal (Pb) Menggunakan Kiambang (Salvinia molesta) pada Ambang Batas, Kualitas Air Irigasi
}

\author{
Diterima 28 Maret 2018, Disetujui 2 April 2018, Dipublikasikan April 2018
}

\author{
S Diliarosta ${ }^{1 \text { a) }}$ \\ ${ }^{1}$ Departemen Pendidikan IPA, Universitas Negeri Padang, Jl. Prof. Dr. Hamka, Air \\ Tawar, Padang, Indonesia \\ ${ }^{\text {a)} E-m a i l: ~ s k u n d a 2 i s b e r d @ g m a i l . c o m ~}$
}

\begin{abstract}
Abstrak. Sumber daya alam yang begitu dekat dengan manusia adalah air, khususnya air sungai. Peningkatan beban pencemaran terhadap air sungai yang terus menerus akan menjadi penyebab utama menurunnya kualitas air sungai saat ini. Gangguan fisik, kimia dan biologi akan menimpa masyarakat bila mengkonsumsi air sungai yang sudah tercemar oleh limbah industri dan pemukiman baik secara langsung maupun tidak langsung dan perlu adanya upayaupaya pengendalian pencemaran lingkungan. Logam berat, seperti merkuri $(\mathrm{Hg})$, timbal $(\mathrm{Pb})$, arsenik (As), kadmium (Cd), kromium (Cr), seng ( $\mathrm{Zn})$, dan nikel (Ni), merupakan salah satu bentuk materi anorganik yang sering menimbulkan berbagai permasalahan yang cukup serius pada perairan khususnya limbah timbal $(\mathrm{Pb})$ yang masuk ke perairan yang dimanfaatkan untuk aktivitas pertanian. Kiambang juga mempunyai kemampuan hidup yang luar biasa karena dapat tumbuh hidup baik pada media air manapun walaupun media tersebut memiliki sedikit nutrient untuk pertumbuhannya. Keistimewaan ini menyebabkan kiambang dijadikan sebagai filter biologis yang dapat menyerap logam berat.
\end{abstract}

Kata kunci: Pecemaran air, Logam berat,Fitoremidiasi, Tanaman Kiambang.

\section{Pendahuluan}

Air merupakan salah satu sumber daya alam yang memiliki fungsi sangat penting bagi kehidupan manusia, serta makhluk hidup lainnya sehingga harus dijaga kualitasnya untuk generasi sekarang dan yang akan datang serta demi tercapainya keseimbangan ekosistem. Sungai sebagai salah satu sumber daya air yang selama ini telah dimanfaatkan sebagai sumber air baku air minum, sumber air sektor industri, pengairan, sebagai badan air penerima berbagai limbah dan lain-lain. Oleh karena itu, untuk melestarikan sumber daya air diperlukan upaya pengelolaan kualitas air dan pengendalian pencemaran air secara bijaksana dengan memperhatikan keseimbangan ekologis.

Dalam beberapa tahun ke depan, penggunaan air akan semakin meningkat. Air tidak bisa dilepaskan dari budidaya pertanian. Karena tanpa air, pertanian tidak berarti apa-apa. Peningkatan beban pencemaran terhadap air sungai yang terus menerus akan menjadi penyebab utama menurunnya kualitas air sungai saat ini. Gangguan fisik, kimia dan biologi akan menimpa masyarakat bila mengkonsumsi air sungai yang sudah tercemar oleh limbah industri dan pemukiman baik secara langsung maupun tidak langsung. ( Berd dan Diliarosta, 2015).

Timbal $(\mathrm{Pb})$ termasuk dalam kelompok logam yang beracun dan berbahaya bagi kehidupan makhluk hidup yang disebut juga sebagai non essential trace element yang paling tinggi kadar racunnya dalam tubuh manusia. Limbah yang mengandung $\mathrm{Pb}$ dapat berasal dari limbah penggunaan batu bara dan minyak, limbah pabrik peleburan besi dan baja, pabrik produksi semen dan limbah dari penggunaan logam yang bersangkutan untuk hasil produksinya, seperti: pabrik baterai, tekstil, pestisida, gelas, keramik dan lain-lain (Darmono, 2001) Air sungai yang telah tercemar limbah industri dan limbah penduduk yang mengandung unsur-unsur logam berat yang kemudian digunakan sebagai air irigasi sawah atau tanaman sayuran lainnya akan menyebabkan tanaman tersebut mengandung logam berat. 
Sekretariat: Jurusan Pendidikan IPA, Fakultas Matematika dan Ilmu Pengetahuan Alam, Universitas Negeri Padang - Jl. Prof. Dr. Hamka, Air Tawar Padang, Sumatera Barat

E-mail :prodiipa16@gmail.com, Halaman website : http://www.semesta.ppj.unp.ac.id/index.php/semesta.

Jurnal SEMESTA, Vol.01, No.01, 2017 pp. 29-33

Berdasarkan uraian diatas, perlu adanya upaya-upaya pengendalian pencemaran lingkungan khususnya limbah timbal $(\mathrm{Pb})$ yang masuk ke perairan yang dimanfaatkan untuk aktivitas pertanian. Fitoremediasi (Phytoremediation) merupakan suatu sistem dimana tanaman tertentu secara sendiri atau bekerja sama dengan mikroorganisme dalam media (tanah, koral dan air), dapat mengubah zat kontaminan (pencemar/polutan) menjadi kurang atau tidak berbahaya bahkan menjadi bahan yang berguna secara ekonomi.

Pada penelitian ini tanaman yang akan dimanfaatkan untuk proses penurunan konsentrasi timbal $(\mathrm{Pb})$ adalah tanaman Kiambang (Salvinia molesta) yang merupakan jenis tanaman yang potensial sebagai pengikat logam berat. Pemilihan tanaman kiambang pada penelitian ini berdasarkan pada pertimbangan-pertimbangan antara lain: tanaman kiambang merupakan jenis tanaman yang banyak dijumpai di Indonesia, tidak memerlukan perawatan khusus, dan pemeliharaannya sangat mudah.

Berdasarkan hal di atas, maka penulis tertarik untuk melakukan penelitian mengenai "Fitoremediasi Logam Timbal (Pb) Menggunakan Kiambang (Salvinia molesta) Pada Ambang Batas Kualitas Air Irigasi”. Tujuan dari penelitian ini adalah untuk Menganalisis daya serap tanaman kiambang terhadap air yang tercemar logam berat $\mathrm{Pb}$.

\section{Metode Penelitian}

Pada Penelitian ini dilakukan untuk mengukur kemampuan tanaman air dalam menurunkan konsentrasi logam berat Timbal $(\mathrm{Pb})$ dengan menggunakan tanaman kiambang (Salvinia molesta) sebagai agen fitoremediasi dilakukan dengan perlakuan konsentrasi yaitu $175 \%$ dari baku mutu kualitas air untuk irigasi (pertanian) dengan pengulangan sebanyak 3 kali.

Pada penelitian ini konsentrasi timbal $(\mathrm{Pb})$ yaitu $175 \%$ dari standar baku mutu air untuk irigasi (pertanian) dengan 3 (tiga) kali ulangan, ini bertujuan untuk mendapatkan waktu yang dibutuhkan kiambang dalam menurunkan konsentrasi logam berat Timbal $(\mathrm{Pb})$ tersebut. Pemilihan konsentrasi ini berdasarkan dari penelitian sebelumnya yang telah dilakukan oleh Yusri Jamal (2011), diketahui bahwa pada konsentrasi Timbal $(\mathrm{Pb}) 150 \%$, tanaman kiambang masih dapat menyerap Timbal $(\mathrm{Pb})$ secara baik, maka dari itu pada penelitian ini akan dilakukan penyerapan logam $\mathrm{Pb}$ dengan tanaman kiambang pada tingkat konsentrasi Timbal $(\mathrm{Pb}) 175 \%$ dari baku mutu kualitas air untuk irigasi (pertanian).

Standar baku mutu air kelas IV untuk Timbal $(\mathrm{Pb})$ adalah $1 \mathrm{mg} / \mathrm{l}$. Untuk $175 \%$ konsentrasi Timbal $(\mathrm{Pb})$ menjadi $1,75 \mathrm{mg} / \mathrm{l}$.

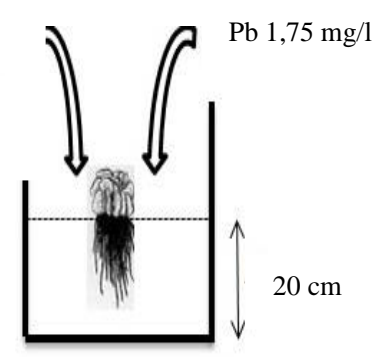

Gambar 1. Perlakuan Penelitian

Pengamatan terhadap masing-masing perlakuan dilakukan setiap 24 jam. Pengamatan selesai jika penurunan konsentrasi logam berat telah berada pada baku mutu untuk pertanian. Alat yang digunakan pada penelitian ini adalah ember plastik, kayu untuk pengaduk, botol sampel dan Atomic Absorption Spekhtropotometer (AAS). Bahan yang digunakan adalah logam berat Timbal $(\mathrm{Pb})$. Sedangkan fitoremediasi yang digunakan adalah tanaman kiambang (Salvinia molesta). Penelitian ini dilakukan di Jalan Wak Ketok, Koto Parak - Ambacang no. 50, Padang. Sedangkan Analisis kadar logam berat Timbal $(\mathrm{Pb})$ dilakukan di laboratorium. 
Sekretariat: Jurusan Pendidikan IPA, Fakultas Matematika dan Ilmu Pengetahuan Alam, Universitas Negeri Padang - Jl. Prof. Dr. Hamka, Air Tawar Padang, Sumatera Barat

E-mail :prodiipa16@gmail.com, Halaman website : http://www.semesta.ppj.unp.ac.id/index.php/semesta.

Jurnal SEMESTA, Vol.01, No.01, 2017 pp. 29-33

\section{Hasil dan Pembahasan}

\subsection{Kondisi Umum}

Tanaman Kiambang (Salvinia molesta) merupakan tanaman air dimana akar tanaman tidak tertanam melainkan mengapung di permukaan air karena itulah dinamakan floating plant. Tanaman ini hidup dari menyerap udara dan unsur hara yang terkandung di dalam air.

Langkah awal pada penelitian ini adalah mengukur kandungan logam berat timbal $(\mathrm{Pb})$ dalam air yang akan digunakan sebelum perlakuan penambahan konsentrasi timbal $(\mathrm{Pb})$. Hal ini dilakukan untuk memperoleh data awal karakteristik air di dalam ember tersebut. Alat yang digunakan untuk mengamati konsentrasi timbal $(\mathrm{Pb})$ adalah Atomic Absorption Spekhtropotometer (AAS). Hasil analisis data awal kandungan logam berat timbal $(\mathrm{Pb})$ sebelum perlakuan penambahan konsentrasi timbal yang diperoleh adalah $0,043 \mathrm{mg} / \mathrm{l}$.

Dari hasil data awal yang diperoleh menunjukkan bahwa konsentrasi logam berat timbal $(\mathrm{Pb})$ sebelum perlakuan penambahan konsentrasi air adalah sangat kecil dan jauh dibawah batas baku mutu kualitas air pertanian (kualitas air kelas IV). Oleh karena itu, air dalam masing-masing perlakuan dilakukan penambahan larutan logam berat timbal $(\mathrm{Pb})$ sebanyak $175 \%$ dari standar baku mutu kualitas air untuk pertanian dengan volume air 12,764 liter.

Tanaman kiambang yang dipilih pada penelitian ini adalah tanaman yang mempunyai kesamaan morfologi dan ukuran akar yang relatif sama yaitu dengan panjang akar rata-rata $10 \mathrm{~cm}$. Banyaknya tanaman kiambang yang digunakan berdasarkan biomassa yang sama untuk setiap perlakuan penelitian yaitu 200 gram/ember.

Parameter yang diamati pada setiap pengukuran penelitian ini adalah bagaimana tingkat penurunan kadar konsentrasi timbal $(\mathrm{Pb})$ pada tanaman kiambang dengan konsentrasi larutan timbal $(\mathrm{Pb}) 1,75 \mathrm{mg} / \mathrm{l}$. Sampel pengukuran diambil setiap 24 jam (1 hari) untuk melihat tingkat penurunan konsentrasi logam berat timbal $(\mathrm{Pb})$ oleh tanaman kiambang. Dengan konsentrasi air awal $1,75 \mathrm{mg} / \mathrm{l}$ dilakukan penelitian menggunakan tanaman kiambang selama 7 hari.

\subsection{Konsentrasi Awal Larutan Timbal (Pb) $1,75 \mathrm{mg} / \mathrm{l}$}

Setelah dilakukan penelitian maka berdasarkan analisis dan perhitungan dapat dilihat tingkat kecenderungan penurunan konsentrasi logam berat timbal $(\mathrm{Pb})$ oleh tanaman kiambang dengan volume air 12,764 liter dan konsentrasi awal $1,75 \mathrm{mg} / \mathrm{l}$, seperti terlihat pada Tabel 1.

Tabel 1. Laju Penurunan Konsentrasi Timbal $(\mathrm{Pb})$ oleh Tanaman Kiambang

\begin{tabular}{cc}
\hline $\begin{array}{c}\text { Waktu } \\
\text { (Jam) }\end{array}$ & Konsentrasi Awal 1,75 mg/l \\
\hline 0 & 1,750 \\
\hline 24 & 1,599 \\
\hline 48 & 1,495 \\
\hline 72 & 1,357 \\
\hline 96 & 1,195 \\
\hline 120 & 1,038 \\
\hline 144 & $\mathbf{0 , 8 5 2}$ \\
\hline
\end{tabular}

Dari Tabel 1 terlihat bahwa tanaman kiambang pada konsentrasi awal larutan logam $\mathrm{Pb}$ 1,75 mg/l mampu memulihkan kualitas air yang telah tercemar logam berat timbal $(\mathrm{Pb})$ hingga pada batas baku mutu kualitas air. Penurunan konsentrasi logam berat timbal $(\mathrm{Pb})$ pada tanaman kiambang terjadi pada waktu ke- 144 jam yaitu $0,852 \mathrm{mg} / \mathrm{l}$, setelah dilakukannya perlakuan fitoremediasi dengan menggunakan tanaman kiambang (Salvinia molesta) maka larutan timbal $(\mathrm{Pb})$ telah berada dibawah 
Sekretariat: Jurusan Pendidikan IPA, Fakultas Matematika dan Ilmu Pengetahuan Alam, Universitas Negeri Padang - Jl. Prof. Dr. Hamka, Air Tawar Padang, Sumatera Barat

E-mail :prodiipa16@gmail.com, Halaman website : http://www.semesta.ppj.unp.ac.id/index.php/semesta.

Jurnal SEMESTA, Vol.01, No.01, 2017 pp. 29-33

baku mutu air untuk pertanian $(1 \mathrm{mg} / \mathrm{l})$. Hal ini menunjukkan bahwa tanaman kiambang memiliki kemampuan untuk menurunkan konsentrasi pencemaran logam berat timbal $(\mathrm{Pb})$. Untuk melihat kecenderungan waktu penurunan konsentrasi logam berat timbal $(\mathrm{Pb})$ pada tanaman kiambang dapat dilihat pada Gambar 2.

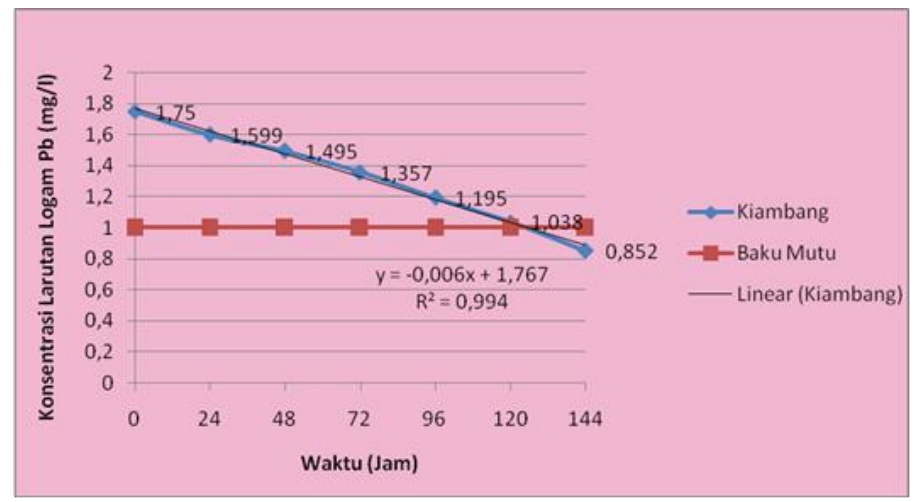

Gambar 2. Laju Penurunan Konsentrasi Larutan Timbal (Pb)

Pada Gambar 2 dapat dilihat seberapa lama waktu yang dibutuhkan oleh tanaman kiambang dalam menurunkan logam berat timbal $(\mathrm{Pb})$ hingga mencapai nilai konsentrasi logam berat timbal $(\mathrm{Pb})$ dibawah ambang batas baku mutu kelas IV untuk kualitas air irigasi (pertanian). Penurunan konsentrasi oleh tanaman kiambang (Salvinia molesta) yaitu pada waktu ke- 144 jam dengan nilai $0,852 \mathrm{mg} / \mathrm{l}$, hal ini dikarenakan tanaman kiambang merupakan salah satu tanaman fitoremediator logam berat $\mathrm{Pb}$ yang mampu beradaptasi pada lingkungan dengan kondisi salinitas rendah $(<10 \% \mathrm{o})$ (Biber, 2008). Selain itu, secara morfologi tanaman kiambang (Salvinia molesta) memiliki diameter daun yang relatif kecil (rata-rata $2-4 \mathrm{~cm}$ ) tetapi memiliki perakaran yang lebat dan panjang (Oliver, 1993). Dari hasil grafik kiambang ini ternyata didapatkan korelasi positif antara waktu (X) dan konsentrasi (Y). Berarti, semakin lamanya waktu penurunan yang diamati maka meningkat pula proses penurunan konsentrasi timbal $(\mathrm{Pb})$. Besar hubungannya ditentukan oleh koefisien determinasi $\mathrm{R} 2=$ 0,994 atau sebesar $99,4 \%$. Ini berarti bahwa meningkatnya penurunan konsentrasi timbal $(\mathrm{Pb})$ sebesar $99,4 \%$ dapat dijelaskan melalui hubungan linier yang persamaannya y $=-0,147 \mathrm{x}+1,914$, sisanya ditentukan oleh keadaan lain. Perhitungan untuk mendapatkan lama waktu untuk mencapai batas baku mutu kualitas air pertanian dapat dilihat pada Lampiran 5.

Persentase penurunan konsentrasi logam berat timbal $(\mathrm{Pb})$ dapat diperoleh dengan persamaan IFR (Indeks Fitoremediasi) yaitu dengan membandingkan konsentrasi awal dengan konsentrasi sesudah kontak oleh tanaman kiambang terhadap lama waktu kontak yang dinyatakan dalam persen (\%) dapat dilihat pada Gambar 3.

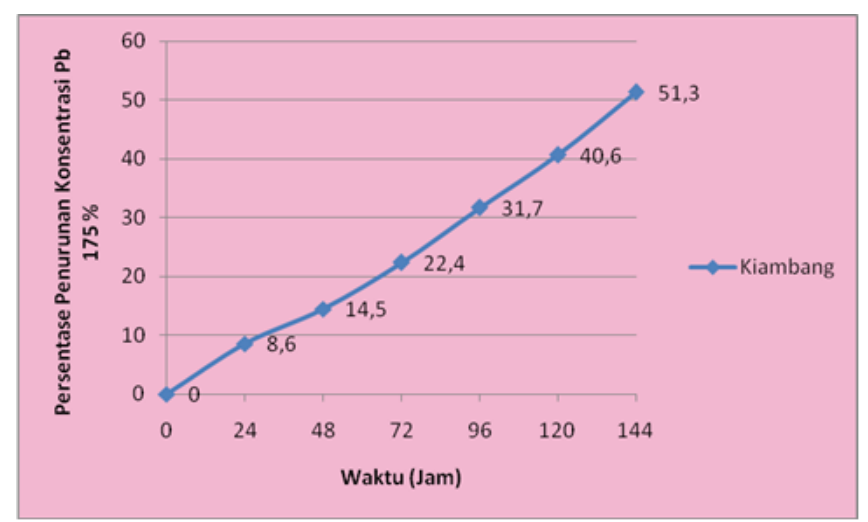

Gambar 3. Persentase Penurunan Timbal $(\mathrm{Pb})$ 
Sekretariat: Jurusan Pendidikan IPA, Fakultas Matematika dan Ilmu Pengetahuan Alam, Universitas Negeri Padang - Jl. Prof. Dr. Hamka, Air Tawar Padang, Sumatera Barat

E-mail :prodiipa16@gmail.com, Halaman website : http://www.semesta.ppj.unp.ac.id/index.php/semesta.

Jurnal SEMESTA, Vol.01, No.01, 2017 pp. 29-33

Berdasarkan hasil penelitian yang telah dilakukan dengan konsentrasi awal 1,75 mg/l selama 7 hari (144 jam), maka dapat dilihat persentase penurunan logam berat timbal $(\mathrm{Pb})$ pada tanaman kiambang mencapai 51,3\%. Dengan demikian, maka dapat disimpulkan bahwa tanaman kiambang mampu menyerap beban pencemar dengan baik. Dari Gambar 7 menunjukkan bahwa persentase penurunan kadar logam berat timbal $(\mathrm{Pb})$ dengan konsentrasi $1,75 \mathrm{mg} / \mathrm{l}$ mengalami penurunan. Kondisi ini menunjukkan kadar timbal $(\mathrm{Pb})$ dalam perairan mempengaruhi pertumbuhan tanaman yang secara tidak langsung juga mempengaruhi daya serap tanaman, sehingga proses penyerapan logam berat timbal $(\mathrm{Pb})$ dengan konsentrasi tinggi akan menjadi lambat atau lama. Hal ini diperkuat oleh pendapat Lahuddin (2007) dalam Yusri Jamal (2011) yang menyatakan bahwa kelebihan kadar timbal $(\mathrm{Pb})$ media yang melewati ambang batas akan menjadi pemicu terjadinya keracunan khususnya pada tanaman.

\section{Kesimpulan}

Dari hasil penelitian yang telah dilakukan dapat disimpulkan bahwa kemampuan tanaman kiambang dalam menyerap logam berat timbal $(\mathrm{Pb})$ pada konsentrasi $1,75 \mathrm{mg} / \mathrm{l}$ membutuhkan waktu 144 jam yaitu mencapai konsentrasi $0,852 \mathrm{mg} / \mathrm{l}$. Hasil yang diperoleh tersebut menunjukkan bahwa konsentrasi logam berat timbal $(\mathrm{Pb})$ telah berada dibawah baku mutu kualitas air untuk irigasi / pertanian $(1 \mathrm{mg} / \mathrm{l})$. Persentase penurunan logam berat timbal $(\mathrm{Pb})$ oleh tanaman kiambang dengan konsentrasi $1,75 \mathrm{mg} / \mathrm{l}$ setelah waktu 144 jam adalah 51,3 \%. Hal ini menunjukkan bahwa tanaman kiambang dapat digunakan sebagai agen fitoremediasi logam berat $\mathrm{Pb}$.

\section{Daftar Pustaka}

Berd,I. dan Skunda,D 2015. Mengkritisi Banjir, Longsor, Kekeringan dan Lingkungan dalam Era Perobahan Iklim Global. Andalas University Press.

Biber, Patrick D. 2008. Determining Salinity-Tolerance Of Giant Salvinia Using Chlorophyll FluoreScence. Gulf and Caribbean Research Vol. 21.

Darmono. 2001. Lingkungan Hidup dan Pencemaran, Hubungan Dengan Toksikologi Senyawa Logam. UI-Press. Jakarta.

Jamal, Y. 2011. Pemulihan Kualitas Air Tercemar Logam Berat Timbal dan Tembaga Menggunakan Tanaman Kiambang untuk Ambang Batas Kualitas Air Irigasi. [skripsi]. Padang: Teknologi Petanian, Unand. 